\title{
The Difference of Serum Vitamin E Levels between Adolescent Patients with and without Acne Vulgaris
}

\author{
Wahyunita Desi Ratnaningtyas, Sawitri, Dwi Murtiastutik, Afif Nurul Hidayati \\ Departement of Dermatology and Venereology \\ Faculty of Medicine Universitas Airlangga/Dr. Soetomo General Academic Teaching Hospital \\ Surabaya
}

\begin{abstract}
Background: Acne vulgaris (AV) is a chronic inflammatory disease of the pilosebaceous unit, particularly among adolescents. The pathogenesis of AV is multifactorial, developing research studies the role of free radicals and antioxidants imbalance that cause oxidative stress in AV. The main antioxidant found in the skin is vitamin E, which functions as a protector against lipid peroxide. Purpose: To compare serum vitamin E levels in adolescents with AV and healthy adolescents without AV (controls). Methods: This is a cross-sectional observational analytic study that involved 17 adolescents with AV and 17 controls in Dermatology and Venereology Outpatient Clinic Dr. Soetomo General Academic Hospital Surabaya. The subjects have met the inclusion and exclusion criterias. Result: The mean of vitamin E level in adolescent patients with AV was $7.8 \pm 1.07 \mathrm{mg} / \mathrm{mL}$ and $10 \pm 1.06 \mathrm{mg} / \mathrm{mL}$ in controls with the $\mathrm{p}$-value in this study was $\mathrm{p}=$ 0.0001. Conclusion: It was found that serum vitamin E levels in adolescent AV patients were significantly lower than the controls. Further research is required to find out more about the role of antioxidants in the pathogenesis of AV.
\end{abstract}

Key words: acne vulgaris, adolescent, vitamin E, antioxidant.

Correspondence address: Sawitri, Department of Dermatology and Venereology, Faculty of Medicine, Universitas Airlangga, Dr. Soetomo General Academic Teaching Hospital, Jl. Prof. Dr. Moestopo No. 6-8, Surabaya, 60131, Indonesia. Telephone: +6231-5501609, e-mail: sawitri.rh@gmail.com.

\section{INTRODUCTION}

Acne vulgaris (AV) is a chronic inflammatory disease of the pilosebaceous unit, particularly among adolescents. Most cases of AV are accompanied by a pleomorphic variation of the lesion, such as comedones, papules, pustules, and nodules. ${ }^{1}$ Acne vulgaris affects $80 \%$ of people at various ages between 11-30 years, prevalence in adolescents aged 10-19 years according to World Health Organization (WHO) ranges from 35-90\%. Acne vulgaris occurs from infants to adults with a peak age of 16-19 years in males adolescent or $14-17$ years in female adolescents. As much as $67.2 \% \mathrm{AV}$ cases in the Dermatology and Venereology Outpatient Clinic Dr. Soetomo General Academic Hospital Surabaya in 2009 were adolescents with a female to male ratio of $3: 1$. Acne vulgaris is one of the top 10 most common diseases in the Dermatology and Venereology Outpatient Clinic Dr. Soetomo General Academic Hospital Surabaya, with the prevalence of cases in the year of 2015, 2016 and 2017, respectively at 14.54\%, $13.14 \%$, and 9.54\%; and respectively $29.2 \%, 35.4 \%$ and $37.9 \%$ of the cases were adolescents. Acne vulgaris can last for years and cause permanent disability and scarring which can effect on psychosocial development. ${ }^{2,3}$

Acne vulgaris is a common dermatological condition characterized by excess production of sebum due to hormones, follicular hyperkeratinization, and chronic inflammation in the pilosebaceous unit. ${ }^{4,5}$ Acne vulgaris in puberty occurs because of an increase in androgen hormones. Increasing androgen hormones will cause an increase in the size of the sebaceous glands that stimulates sebum production. Sebum clogging in the hair follicles will trigger the formation of comedones and provide a growth medium for Propionibacterium acnes (P.acnes).

Research on the etiopathogenesis of AV especially the role of free radicals and antioxidants is currently being developed. The skin is constantly exposed to oxidative stress induced by reactive oxygen species (ROS) produced both from endogenous sources (oxygen metabolism) and external pro-oxidants (radiation exposure, air pollution, oxygen intoxication, cigarettes, and alcohol). Reactive oxygen species mediates oxidative stress through interactions of free radicals with cellular molecules such as lipids, carbohydrates, proteins, and nucleic acids which then cause inflammatory reactions. Over the past few years, it has been known that patients with AV experience increasing oxidative stress both systemically and cutaneously. ${ }^{6,7}$ A research conducted by Hani et al. in 
2013 about biochemical markers of oxidative and nitrosative stress in $\mathrm{AV}$ found the role of biochemical markers of protein oxidation, lipid peroxide, or nitrosative stress on the development of AV. ${ }^{8}$

To deal with the harmful effects of ROS, skin is equipped with antioxidant defense mechanisms to prevent the formation of ROS in the form of enzymatic antioxidants and non-enzymatic antioxidants. ${ }^{9}$ Among these antioxidants, $\alpha$-tocopherol is the main form of vitamin $\mathrm{E}$ and an important fatsoluble antioxidant. In $\mathrm{AV}$, low level of vitamin $\mathrm{E}$ can cause the formation of oxidative stress in the pilosebaceous unit, giving rise to an ideal microaerophilic environment that will increase the colonization of $P$. acnes. In addition, $\alpha$-tocopherol is a fat-soluble vitamin that works to break the chains during the lipid peroxidation process. Between the skin surface lipids, there is squalene, a triterpenoid molecule specific to human sebum. Its oxidation produces squalene peroxide which is proven to be comedogenic and increases sebum production. The presence of vitamin $\mathrm{E}$ in the skin plays a role in limiting the potentially harmful effects of squalene peroxide. In addition to releasing inflammatory mediators, squalene peroxide can also be comedogenic. ${ }^{10-12}$

El-Akawi et al. in 2006 conducted plasma vitamin E level examination in 100 patients with severe, moderate, and mild AV and 100 control subjects. The severity of AV is determined based on the Global Acne Grading System (GAGS). The results showed that vitamin $E$ levels were significantly lower in patients with severe AV compared with moderate AV, mild AV, and controls. ${ }^{13}$ Ozuguz et al. in 2013 conducted studies on vitamin $\mathrm{A}$ and $\mathrm{E}$ levels examination in 94 patients with mild, moderate, and severe AV compared with 56 controls who did not suffer from AV. The study found that vitamin E levels were significantly lower in patients with $\mathrm{AV}$ than in controls. $^{14}$

This study aims to compare the serum vitamin $\mathrm{E}$ levels in adolescent AV patients with adolescent without AV in the Dermatology and Venereology Outpatient Clinic Dr. Soetomo General Academic Hospital Surabaya. It is expected that this research can provide scientific contributions and can be used as a basis for further research on serum vitamin $E$ levels in adolescent patients with AV.

\section{METHODS}

This is a cross-sectional observational analytic study that aims to find out serum vitamin $E$ levels in adolescents with $\mathrm{AV}$ and adolescents without $\mathrm{AV}$. This study was conducted by consecutive sampling from November 2018 until January 2019. The samples were adolescent patients with $\mathrm{AV}$ and adolescents without AV who visited the Medical Cosmetic Division of Dermatology and Venereology Outpatient Clinic Dr. Soetomo General Academic Hospital Surabaya; and met the inclusion and exclusion criterias. The inclusion criterias of samples were adolescent patients aged 10-19 years with a diagnosis of $\mathrm{AV}$, not taking drugs containing vitamin E 3 days before examination, and willing to sign the informed consent. The inclusion criterias for the control group were healthy adolescent patients, no history of AV, no history of AV exacerbations, no history of AV scars at the time of the inspection, and willing to participate and to sign the informed consent. The exclusion criterias of samples were patients with severe systemic disease (cardiovascular disease, asthma, psoriasis vulgaris, diabetes mellitus, malignancy, liver dysfunction), Human Immunodefficiency Virus-related immunodeficiency, autoimmune diseases (systemic lupus erythematosus, rheumatoid arthritis), chronic diseases (tuberculosis infection), and polycystic ovary syndrome based on history and clinical examination, pregnant and lactating women, have a history of smoking and drinking alcohol. All research samples underwent historytaking, physical examination, and examination of serum vitamin E level using the High-Performance Liquid Chromatography (HPLC) method. The data were collected and arranged in tables and graphs.

\section{RESULT}

The number of male subjects in AV group and control group were more than female subjects. In the AV group, there were 13 male subjects (76.5\%) and 4 female subjects $(23.5 \%)$. In the control group, there were 11 male subjects $(64.7 \%)$ and 6 female subjects (35.3\%). There were 34 subjects with median age 17 years old (15-19 years old) in the AV group and 18 years old (16-19 years old) in the control group (Table $1)$.

Fifteen subjects in the AV group and 17 subjects in the control group were unemployed. In the AV group, there were 6 high schools graduates, 1 junior high school graduate, and 10 vocasional school graduates. In the control group, there were 2 high school graduates and 15 vocational school graduates. All subjects (100\%) were unmarried. Most subjects have AV onset for 2 years $(41.2 \%)$. No comorbidities observed in all subjects $(100 \%)$. There were 11 subjects $(64.7 \%)$ that confirmed they have a family member with AV history, and 6 subjects (35.3\%) claimed that they do not have a family member with AV history. Twelve subjects (70.6\%) in the AV group 
claimed that the AV was stress triggered. Eleven subjects $(64.7 \%)$ in the AV group had never received any forms of therapy, either oral or topical antibiotics, soap for acne, sunscreen, and other topical therapies. All subjects $(100 \%)$ were found often consume steamed rice, 9 subjects in the AV group (52.9\%) often consume fried chicken, and 8 subjects (47.1\%) in the control group often consume fresh spinach. The basic data of this research subjects can be seen in Table 2 .

Table 1. Sosiodemography characteristic of age and sex of the subjects

\begin{tabular}{llll}
\hline Variabel & Acne vulgaris & Control & p Value \\
\hline Sex $(\%)$ & $13(76.5)$ & $11(64.7)$ & 0.707 \\
Male & $4(23.5)$ & $6(35.3)$ & \\
Female & 17 & 19 & 0.013 \\
\hline Age & $15-19$ & $16-19$ & \\
Median & Range Age & & \\
\hline
\end{tabular}

Table 2. Basic data of research subjects

\begin{tabular}{|c|c|c|}
\hline Variables & Acne Vulgaris, $n=17(\%)$ & Control, $\mathrm{n}=17(\%)$ \\
\hline Age & $17(15-19$ years old $)$ & $18(16-19$ years old $)$ \\
\hline \multicolumn{3}{|l|}{ Sex } \\
\hline Male & $13(76.5)$ & $11(64.7)$ \\
\hline Female & $4 \quad(23.5)$ & $6 \quad(35.3)$ \\
\hline \multicolumn{3}{|l|}{ Formal Education } \\
\hline Middle School & $1(5.8)$ & $0(0)$ \\
\hline High School & $6 \quad(35.3)$ & $2(11.7)$ \\
\hline Vocational School & $10(58.8)$ & $15(88.2)$ \\
\hline \multicolumn{3}{|l|}{ Employment Status } \\
\hline Employed & $2(11.8)$ & $0(0)$ \\
\hline Unemployed & $15(88.2)$ & $17(100)$ \\
\hline \multicolumn{3}{|l|}{ Marital Status } \\
\hline Married & $0(0)$ & $0(0)$ \\
\hline Not Married & $17(100)$ & $17(100)$ \\
\hline \multicolumn{3}{|l|}{ Onset (years) } \\
\hline 1 & $5(29.4)$ & $0(0)$ \\
\hline 2 & $7(41.2)$ & $0(0)$ \\
\hline 3 & $4(23.5)$ & $0(0)$ \\
\hline 4 & $1(5.9)$ & $0(0)$ \\
\hline \multicolumn{3}{|l|}{ Comorbidity } \\
\hline Yes & $0(0)$ & $0(0)$ \\
\hline No & $17(100)$ & $0(0)$ \\
\hline \multicolumn{3}{|l|}{ Family History } \\
\hline Yes & $11(64.7)$ & $0(0)$ \\
\hline No & $6(35.3)$ & $0(0)$ \\
\hline \multicolumn{3}{|l|}{ Stress } \\
\hline Yes & $12(70.6)$ & $0(0)$ \\
\hline No & $5(29.4)$ & $0(0)$ \\
\hline \multicolumn{3}{|l|}{ Therapy } \\
\hline Yes & $6 \quad(35.3)$ & $0(0)$ \\
\hline No & $11(64.7)$ & $0(0)$ \\
\hline \multicolumn{3}{|c|}{ Consumed foods with Vitamin E } \\
\hline Steamed Rice & $17(100)$ & $17(100)$ \\
\hline Fried Chicken & $9(52.9)$ & $4(23.5)$ \\
\hline Fresh Spinach & $4(23.5)$ & $8(47.1)$ \\
\hline
\end{tabular}


The results of serum vitamin $\mathrm{E}$ levels in adolescent patients ranged from $7.82 \pm 1.07 \mathrm{mg} / \mathrm{L}$ in the $\mathrm{AV}$ group and $10 \pm 1.06 \mathrm{mg} / \mathrm{L}$ in the control group, $\mathrm{p}=0.0001(\mathrm{p}<0.05)$. Serum vitamin E levels are shown in Table 3 and Figure 1.

Table 3. Serum vitamin E levels in adolescent patients with acne vulgaris and controls

\begin{tabular}{llll}
\hline Description & $\mathrm{AV}, \mathrm{n}=17$ & Control, $\mathrm{n}=17$ & $\mathrm{p}$ Value \\
Mean & 7.82 & 10.00 & 0.0001 \\
Standard Deviation & 1.07 & 1.06 & \\
Minimum & 6.00 & 8.00 & \\
Maximum & 10.00 & 12.00 & \\
\hline
\end{tabular}

$\mathrm{AV}=$ Acne vulgaris

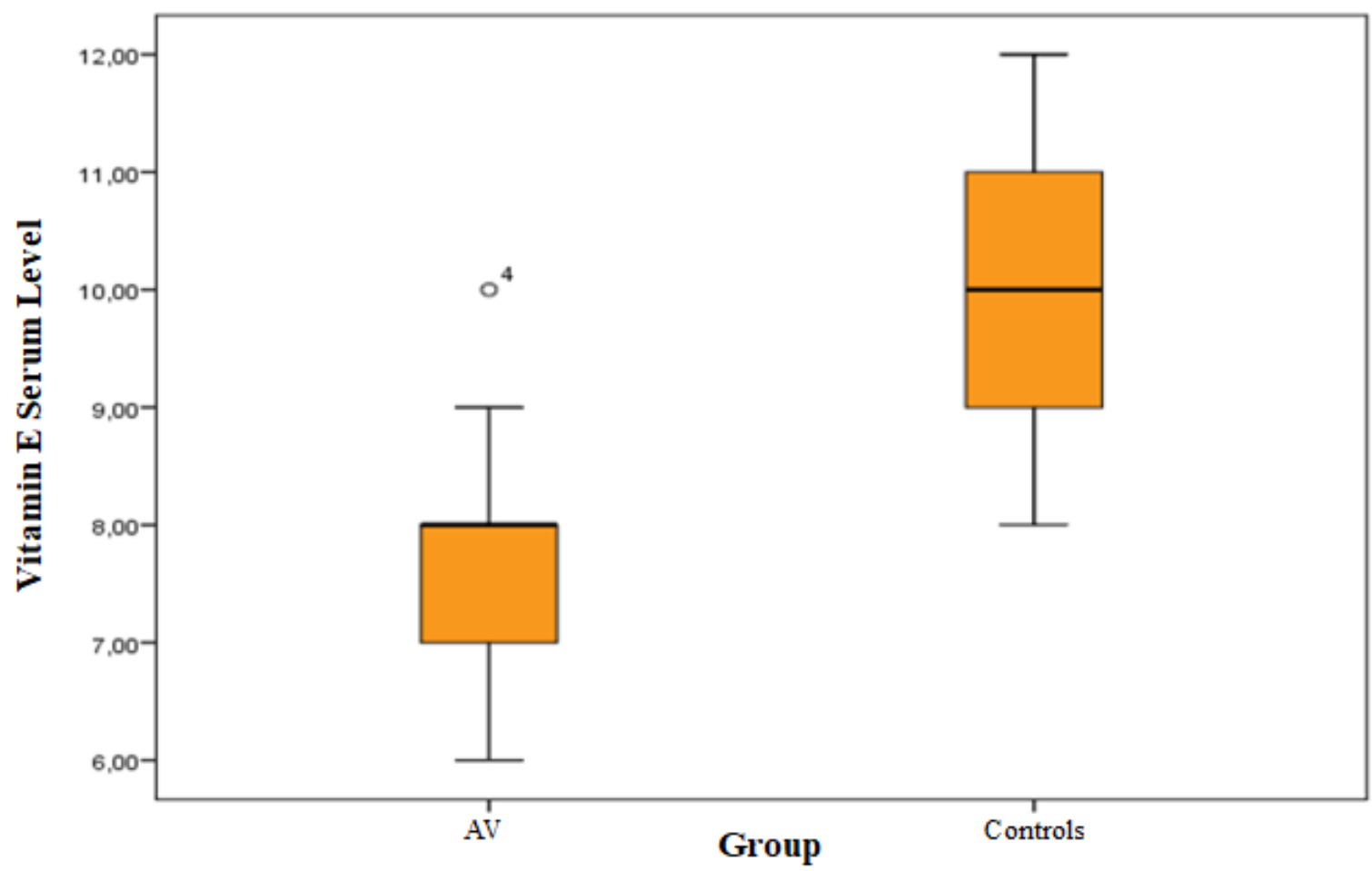

Figure 1. Boxplot graph of vitamin E levels in adolescent patients with Acne vulgaris and controls.

\section{DISCUSSION}

In this study, 13 subjects $(76.5 \%)$ were male.

This data showed that the number of male AV patients is more than female AV patients. Acne vulgaris can affect both men and women. However, several studies found that $\mathrm{AV}$ is more common in male adolescents. Yahya in 2009 conducted a study at a school in Kaduna, Nigeria, reported that there were 379 students with $\mathrm{AV}$, and 198 (52.2\%) of them were male students. ${ }^{15}$ There is research that claimed AV in females emerges sooner, in more severe forms compared to AV cases in males during puberty. Acne vulgaris is found more in male adolescents, but more severe form of $\mathrm{AV}$ is more common in males during puberty, and AV in male adolescents is one of the most visible markers when there is an excess of androgens. ${ }^{16,17}$
This study involved $34 \mathrm{AV}$ subjects with an age range of 10-19 years. The age range was determined by WHO definition on adolescent, which is 10-19 years old. The average age in the AV group was 17 years old (15-19) and 18 years old (16-19) in the control group. This was concordance with a research of Layton AM and Mawson RL, confirming the age range of AV is $15-20$ years old. ${ }^{18}$

There were 15 unemployed subjects $(88.2 \%)$ in the AV group and 17 unemployed subjects (100\%) in the control group. There were only 2 employed subjects $(11.8 \%)$ in the AV group. All subjects, were unmarried. Acne vulgaris is a multifactorial disease with external factors such as stress on working environment. ${ }^{19}$

The onset of AV varies in each age group, more common in puberty, and can continue into young 
adulthood. The results of this study were in line with the research conducted in Saudi Arabia by Darwish in 2013. In his study, $37.8 \%$ of the total sample visited the doctor within 1 year after the symptoms appear. Poli et al. in 2011 discovered the same result; the average AV patients who seek treatment had suffered from AV for more than 12 months (49.6\%). A study conducted by Al Robaee in 2005 on 717 patients found that $40.3 \%$ of patients had been suffered from AV for 3 months. Tallab's study in 2004 found that $76.2 \%$ of patients had suffered more than one year from $\mathrm{AV}{ }^{20,21}$

Most subjects, which were 11 subjects (64.7\%), had a family history of AV. This is in accordance with the research conducted by Ebede et al. in 2009 involving 200 individuals with $\mathrm{AV}$ who stated if they had a family member suffering from $\mathrm{AV} .{ }^{22} \mathrm{~A}$ research by Mariana in 2016 also found supporting results. There were more patients with a family history of AV than without AV. Bagatin et al. found that about half of the adolescent population reported there was father or mother with $\mathrm{AV}^{23} \mathrm{~A}$ study conducted by $\mathrm{Di}$ Landro in 2009 found that AV was influenced by family history, and the prevalence of AV was higher in maternal family history compared to paternal or another family history. The more family members with AV history, the higher chance that other family member to suffer from AV. Genetic influence on AV has been reported in twin studies and several genealogical studies, but only a few of them described the relationship between the two. ${ }^{24}$ Research by Sobjanek suggested that there was a relationship between AV and Human leucocyte antigen (HLA), CYPA1, CYP17, CYP21, MUCI, AR, and MCR-5 genes, with further explanation required. ${ }^{25}$

Stress plays a role in causing AV. There were 12 subjects $(70.6 \%)$ who claimed that stress was the triggering factor of AV. This was accordant with Purwanidyah's study in 2013 on profiles of AV patients in Medan. Stress was reported as a psychological factor that caused AV in $90 \%$ of subjects. ${ }^{26}$ Psychological stress can exacerbate AV. This was consistent with research conducted by Chiu et al. in 2003 on AV severity in students during exam. ${ }^{27}$ Similar results were obtained by Halvorsen et al. in 2009. The research found that AV become worse before and during exams, which was triggered by increased stress experienced by the students. ${ }^{28}$ Elsaie et al. mentioned that corticotropin-releasing hormone (CRH), also known as the stress hormone and $\mathrm{CRH}-\mathrm{R}$ receptors have been found in sebaceous glands. Corticotropin-releasing hormone directly induces lipid production and increases the conversion of dehydroepiandrosterones (DHEAS) to testosterone in sebocytes. This process is suspected of playing an important role in the relationship between stress and sebum production. The sebaceous gland also has receptors for substance $\mathrm{P}$, which is a neuromediator that is released in response to stress. In vitro, substance $P$ stimulates sebaceous secretion. It is postulated that substance $\mathrm{P}$ plays a role in $\mathrm{AV}$ as a response to stress. ${ }^{29}$

Steamed rice was the consumed food in all with total 34 subjects $(100 \%)$, followed by fried chicken in 9 subjects (52.9\%) in AV group, and fresh spinach in 8 subjects $(47.1 \%)$ in the control group. White rice is widely consumed because it is a staple food in Indonesia. The vitamin E content in chickens is 0.86 $\mathrm{mg}$ lower than the vitamin $\mathrm{E}$ content in fresh spinach which is $2.67 \mathrm{mg}$, it is supported by several observational studies that have been conducted to assess the relationship between diet and acne. ${ }^{30,31} \mathrm{~A}$ cross-sectional study by Cordian et al. in 2002 (level of evidence 2) observed two non-westernized populations in the Kitavan islands in Papua New Guinea $(\mathrm{n}=1200)$ and acne hunter-gatherers in Paraguay $(n=112)$ who consumed a low-fat diet and low glycemic index. In both groups, there was no AV observed. ${ }^{32}$ Cross-sectional study by Ikaraoha et al. in 2005 (level of evidence 2) examined 174 Nigerian students, and $75 \%$ of participants believed that oil and fat affected acne. ${ }^{33}$

There are at least 4 important factors that play a role in the pathogenesis of $\mathrm{AV}$, namely follicular epidermal hyperproliferation, increased sebum production, $P$. acnes, and inflammatory reactions. Microbes, genetic, and various environmental factors are also associated with the pathogenesis of AV. 1,4,19 Over the past few years, AV patients experience increasing oxidative stress both systemically and cutaneously. Oxidative stress is an imbalance condition where there are more oxidants than antioxidants. Reactive oxygen species mediates oxidative stress through interactions of free radicals with cellular molecules such as lipids, carbohydrates, proteins, and nucleic acids. Of all these components, lipids are the most sensitive, in which polyunsaturated fatty acids in cell membranes react with ROS to form peroxidation products.

To resolve the harmful effects of ROS, the skin is equipped with antioxidant defense mechanisms in the form of enzymatic antioxidants such as glutathione peroxidase (GSH-Px), catalase (CAT), superoxide dismutase (SOD), and non-enzymatic antioxidants. Non-enzymatic antioxidants found in cells are $\alpha$-tocopherol, ubiquinone, $\beta$-carotene, ascorbate, and glutathione. Among these antioxidants, $\alpha$-tocopherol and $\beta$-carotene are concentrated in the 
cell membrane, in vivo functioning as a protector against lipid peroxide. Inadequate antioxidant protection or increasing production of ROS creates a condition called oxidative stress, which contributes to the emergence of inflammatory skin diseases. Oxidative stress can be found in acne and can play a role in its pathogenesis. ${ }^{34}$ Research conducted in 2013 by Hani et al. on biochemical markers of oxidative and nitrosative stress in $\mathrm{AV}$ found the role of biochemical markers of protein oxidation, lipid peroxide, or nitrosative stress on the development of AV. ${ }^{8}$ Previous research also supports the effect of ROS in the etiopathogenesis of acne. Decreasing activity of SOD and GSH-Px enzymes, in which these enzymes are responsible for the defense of antioxidative reactions, were found in papulopustular acne. The finding was in accordance with the role of ROS in acne. ${ }^{35}$

Vitamin $\mathrm{E}$ is the leading lipophilic antioxidant found in plasma, membranes, and tissues. It helps to protect important cell structures, especially cell membranes, from damage caused by free radicals. Antioxidants that can donate hydrogen atoms are called hydrogen donors. Vitamin $\mathrm{E}$ is located in membranes and lipoproteins, as a hydrogen donor, that can stop the radical chain reaction of lipid peroxidase. Therefore, vitamin $\mathrm{E}$ is called as a chainbreaking antioxidant. Vitamin E (TocH) always donates hydrogen atoms to peroxyl lipid radicals to propagate the chain reaction of lipid peroxide..$^{34,36}$

Low vitamin E levels can lead to the formation of oxidative stress in the pilosebaceous unit, creating an ideal micro-aerophilic environment that will increase the colonization and the proliferation of $P$. acnes. Propionibacterium acnes has an important role in the inflammatory process of AV by producing chemotactic factors for neutrophils. Neutrophils produce free radicals in the form of superoxide anion radicals, hydrogen peroxide, and hydroxyl radicals, which will cause cell damage and worsen the inflammatory process. Inadequate antioxidant protection and increasing production of ROS produce a condition called oxidative stress, which contributes to the emergence of inflammatory skin diseases. Vitamin $\mathrm{E}$ is an important fat-soluble antioxidant. Low vitamin E levels will also increase ROS production that will increase oxidative stress and inflammatory processes which are one of the pathogenesis of $\mathrm{AV} .^{34,36}$ In addition, there is squalene between skin surface lipids, a triterpenoid molecule specific to human sebum, that bind with singlet oxygen, protecting the skin from lipid peroxidase, which sometimes produces oxidation of squalene peroxide that is proven to be comedogenic. The supply of vitamin E to the skin plays a role in limiting squalene peroxide. ${ }^{34,36}$

The mean serum vitamin E levels obtained were $7.8 \mathrm{mg} / \mathrm{L}$ in the AV group and $10 \mathrm{mg} / \mathrm{L}$ in the control group. The normal level of serum Vitamin E is 3-14 $\mathrm{mg} / \mathrm{L}$, therefore, it appeared that vitamin $\mathrm{E}$ levels in AV patients were within normal limits. The statistical test used was the t-test, a comparative study to assess the difference between certain values with the average of the group population. The test results showed that there was a significant difference in serum vitamin $\mathrm{E}$ levels between the AV and control group with lower scores on AV group.

The results were in accordance with the study of El-Akawi et al. in 2006 on vitamin E levels in plasma involving 100 subjects with $\mathrm{AV}$ and 100 control subjects. The severity of AV is determined based on the GAGS. The research results showed that the vitamin $\mathrm{E}$ levels in patients with severe $\mathrm{AV}$ were significantly lower than moderate $\mathrm{AV}$, mild $\mathrm{AV}$, and control subjects. The vitamin E levels in mild and moderate AV were lower than control subjects but still within normal limits. This might be due to the vitamin $\mathrm{E}$ accumulation in cellular membranes, preventing serum vitamin $\mathrm{E}$ levels to decrease rapidly. Insufficient of fruits and vegetable diet causes low vitamin E levels, creating depletion of antioxidants to combat ROS or reactive oxygen radicals produced in the inflammatory phase and promoting the lipid peroxidase process in the patient's skin. ${ }^{13}$ Abulnaja conducted a study in 2009 on oxidant/antioxidant status in obese adult women with AV. The research showed that vitamin E levels significantly lower in non-obese subjects. It might be caused by psychological stress, such as depression and anxiety. Vitamin E contributes to preventive activities against the formation of free radicals such as singlet oxygen, superoxide, and hydroxyl radicals from the formation of $\mathrm{AV} .{ }^{37}$ Ozuguz et al. conducted a study comparing vitamin A and vitamin E levels in 94 subjects with mild, moderate, and severe AV with 56 control subjects without AV. It was found that the vitamin E levels of AV subjects were significantly lower than control subjects, yet still under the normal limit than those without AV. It might be due to a lack of vitamin $\mathrm{E}$ intake in AV patients. It was also found that the AV patients consumed more fast foods, increasing vitamin E requirement as the body also needs vitamin $\mathrm{E}$ for fat metabolism. $^{14}$

Karen E, et al. in 2000 conducted a study on mice with normal vitamin $\mathrm{E}$ levels and exposed the mice to ultraviolet $B$ (UVB) to cause acute chronic damage to the skin (such as pigmentation, burns, and even skin cancer). Vitamin E concentration levels 
were measured in the skin, liver, and fat tissues. Afterward, topical and oral vitamin E were given. Vitamin E concentration in the skin, liver, and fat tissues increased, and significant improvements from UV-induced skin damage such as inflammatory lesions and pigmentation were observed. ${ }^{38}$

Based on research conducted in 17 adolescent patients with $\mathrm{AV}$ and 17 adolescent without $\mathrm{AV}$ who came to Dermatology and Venereology Outpatient Clinic Dr. Soetomo General Academic Hospital Surabaya could be concluded that the average level of vitamin $\mathrm{E}$ serum in adolescent patients with $\mathrm{AV}$ is 7.8 $\mathrm{mg} / \mathrm{L}$, and the average of vitamin $\mathrm{E}$ serum level in control subjects is $10 \mathrm{mg} / \mathrm{L}$ and vitamin E serum level in adolescent with $\mathrm{AV}$ is lower than control subjects. The results of this study are expected to give contributions to further research in determining the role of vitamin $\mathrm{E}$ in the $\mathrm{AV}$ pathogenesis and understanding the effectiveness of vitamin $\mathrm{E}$ for $\mathrm{AV}$ treatment.

\section{REFERENCE}

1. Zaenglein AL, Graber EM, Thiboutot DM, Strauss JS. Acne vulgaris and acneiform eruptions. In: Wolff K, Goldsmith LA, Katz SI, Gilchrest BA, Paller AS, Leffell DJ, editors. Fitzpatrick's Dermatology in General Medicine. $8^{\text {th }}$ ed. New York: McGraw Hill; 2012. p. $897-$ 917.

2. Safitri EY, Sukanto H, Ervianti E. Profil kualitas penderita akne vulgaris di RSUD dr. Soetomo Surabaya : studi menggunakan Cardiff Acne Disability Index (CADI). BIKKK 2010; 22: 815.

3. Kelompok Studi Dermatologi Kosmetik Indonesia. Pedoman tata laksana akne di Indonesia. In: Sjarif M, Arimuko A, Norawati L, Bernadette I, Legiawati L, editors. Pedoman tata laksana akne di Indonesia. Jakarta: Perhimpunan Dokter Spesialis Kulit dan Kelamin Indonesia; 2016. p.1-15.

4. Baran R, Chivot M, Shalita AR, Lewis A, Wechsler A. Acne. Baran R, Maibach HI, penyunting. Textbook of cosmetic dermatology. $5^{\text {th }}$ ed. London: Taylor \& Francis; 2017. p.42334.

5. Briganti S, Picardo M. Antioxidant activity, lipid peroxidation and skin diseases. what's new. J Eur Acad Dermatol Venereol 2003; 17: 663-9.

6. Whitney P, Bowe MD, Patel Nayan, Logan C. Acne vulgaris : the role of oxidative stress and the potential therauphetic value of local and systemic antioxidants. J Drugs Dermatol 2012; 11(6): 742-6.
7. Frei B, Boston, Massachusetts. Reaktive oxygen species and antioxidant vitamin: mechanisms of action. Am J Med 1994; 97: 5S-13S.

8. Hani A, Al-Shobaili, Abdullateef A, Alzolibani, Ahmad A, Al Robae, et al. Biochemical markers of oxidative and nitrosative stress in acne vulgaris : corelation with disease activity. Jour of Clin Lab Analysis 2013; 27(1): 45-52.

9. Fattah NS, Shaheen MA, Ebrahim AA, Okda ES. Tissue and blood superoxide dismutase activities and malaondialdehyde in different clinical severities of acne vulgaris. $\mathrm{Br} J$ Dermatol 2008; 159: 1086-9.

10. Thielen J, Sherry N, Swarna N. Vitamin E : critical review of its current use in cosmetic and clinical dermatology. Dermatol Surg 2005; 31: 805-13.

11. Sarici G, Cinar S, Armutu F, Altinyazar C, Koca $\mathrm{R}$, Tekin NS. Oxidative stress in acne vulgaris. J Eur Acad Dermatol Venereol 2010; 24: 763-7.

12. Wolf G. The discovery of the antioxidant function of vitamin E. J Nutr 2005; 135: 363-6.

13. El-akawi Z, Latif NA, Razzak KA. Does the plasma level of vitamin $A$ and $E$ affect acne condition? Clin and Expert Dermatol 2006; 31: 430-4.

14. Pinar O, Seval D, Ozlem E, Zennure T, Ilknur B. Evaluation of Serum Vitamin A dan E and Zinc levels according to the severity of acne vulgaris. Cutan Ocul Toxicol 2013; 33: 1-4.

15. Yahya H. Acne vulgaris in Nigerian adolescentsprevalence, severity, belief, perceptions, and practices. In Jour of Dermatol 2009; 48: 498505.

16. Adityan B, Thappa DM. Profile of acne vulgaris - a hospital-based study from South Indian. Indian J of Dermatol Venereol and Leprol 2009; 75: 272-8.

17. Arora M, Yadav A, Saini V. Role of hormons in acne vulgaris. J Clin Biochem 2011; 44: 1035 40.

18. Layton AM, Mawson RL. Adult Acne. In: Khanna N, Kubba R. Editors. World Clinics Dermatology Acne. New Delhi: Jaypee Brothers Medical Publishers. 2013. p.128-43.

19. Baumann L, Keri J. Acne (type 1 sensitive skin). Dalam : Baumann L, Saghari S, Weissberg E, penyunting. Cosmetic Dermatology Principles and Practice. Edisi ke-2. New York : Mc Graw Hill; 2009. h.121-7.

20. Darwish MA, Al-Rubaya AA. Knowledge, beliefs, and psychosocial effect of acne vulgaris among Saudi acne patients. ISRN Dermatology 2013; 40: 92-3. 
21. Tallab, TM. Beliefs, perceptions, and psychological impact of acne vulgaris among patients in the Assir region of Saudi Arabia. West Afr J Med 2004; 23(1): 1958-61.

22. Ebede TL, Arch EL, Berson D. Hormonal treatment of acne in woman. J Clin Aesthethic Dermatol 2009; 2: 16-22.

23. Mariana AHS, Hussam AH, Eugen VC, Nicoleta $\mathrm{T}$, Hamida AH, Adriana $\mathrm{C}$, et al. Diet, smoking and family history as potential risk factors in acne vulgaris - a community - based study. Acta Medica Marlslensls 2016; 62(2): 173-81.

24. Di Landro A, Cazzaniga S, Math, Parazzini F, Ingordo V, Cusano F, et al. Family history, body mass index, selected dietary factors, menstrual history, and risk of moderate to severe acne in adolescents and young adults. J Am Acad Dermatol 2012; 67(6): 1129-35.

25. Sobjanek M, Zabtotna M, Wojdyto MS, Nedoszytko B, Michajlowski I. Genetic factors in etiopathogenesis of acne vulgaris. Post Dermatol Alergo 2007; 24(4): 183-7.

26. Purwaningdyah RAK, Jusuf NK. Profil penderita akne vulgaris pada siswa-siswi di SMA Shafiyyatul Amaliyyah Medan. E-journal FK USU 2013; 1(1): 255-7.

27. Chiu A, Chon SY, Kimball AB. The response of the skin disease to stress. Arch Dermatol 2003; 139: 897-900.

28. Halvorsen JA1, Stern RS, Dalgard F, Thoresen M, Bjertness E, Lien L. Suicidal ideation, mental health problems, and social impairment are increased in adolescents with acne: a populationbased study. J Invest Dermatol 2011; 131(2): 363-70.

29. Elsaie ML, Baumann L. Oily skin. In: Baumann L, Saghari S, Weisberg E, Editor. Cosmetic
Dermatology Principles and Practice. $2^{\text {nd }}$ ed. New York: McGraw-Hill.2009; p.75-82.

30. Lamid Astuti. Vitamin E sebagai antioksidan. Media litbangkes 2000; 5: 14-7.

31. Packer L. Vitamin $\mathrm{E}$ is nature's master antioxidant. J Sci Med 1994; 1(1): 54-63.

32. Eitenmiller R, Lee J. Vitamin E. Food chemistry, composition, and analysis. Marcel Dekker Inc 2004; 82: 1-31, 89-135.

33. Cordain L, Lindeberg S, Hurtado M. Acne vulgaris: a disease of Western civilization. Arch Dermatol 2002; 138(12): 1584-90.

34. Ikaraoha CI, Taylor GO, Anetor JI. Demographic features, beliefs, and sociopsychological impact of acne vulgaris among its sufferers in two towns in Nigeria. Online $\mathrm{J}$ Health Allied Sci 2005; 4: 1-6.

35. Traber MG, Packer L. Vitamin E: beyond antioxidant function. Am J Clin Nutr 1995; 62: 1501S-9S.

36. Basak PY, Gultekin F, Kilinc I. The role of antioxidative defense system in papulopustular acne. J Dermatol 2001; 28: 123-7.

37. Aseervatham GS, Sivasudha T, Jeyadevi R, Ananth DA. Environmental factors and unhealthy lifestyle influence oxidative stress in humans. Environ Sci Pollut Res 2013; 20(7): 4356-69.

38. Abulnaja KO. Oxidant/antioxidant status in obese adolescent females with acne vulgaris. Indian $\mathrm{J}$ Dermatol of Dermatol Venereol and Leprol 2009; 54: 36-40.

39. Burke KE, Clive J, Combs G, Commiso J. Effect of topical and oral vitamin $\mathrm{E}$ on pigmentation and skin cancer induced by ultraviolet irradiation in SKH-2 hairless mice. Nutr Cancer 2000; 38(1): 87-97. 